\title{
Analisis Faktor-Faktor yang Mempengaruhi Minat Beli Konsumen: Studi Pada Online Shop Shopee
}

\author{
Mey Sinta Etika Dewi ${ }^{1}$, Andhatu Achsa ${ }^{2 \varpi}$ \\ Jurusan Ekonomi/Program Studi S1 Manajemen, Universitas Tidar, Kota Magelang 56116 \\ ${ }^{\square}$ E-mail : andhatuachsa@untidar.ac.id
}

\begin{abstract}
Online shopping is now mostly done by most people, many people are interested in shopping on online sites because of the safety, convenience, trustworthiness, and shopping experience offered by online sites. The purpose of this research is to analyze the factors that can influence consumer buying interest on the Shopee online shopping site, these factors include the safety factor, convenience factor, trust factor, and shopping experience. The population or object in this study is the residents of Semingkir Village, amounting to 3000 people. The sampling technique in this study is using purposive sampling technique with the criteria that respondents have the same ability to apply online shopping sites, so that the number of samples used is 91 samples. The data analysis method used in this research is by conducting interviews, observations, and literature studies. The results in this study indicate that the safety factor with an average weight of $94.8 \%$, the convenience factor with an average weight of $70.3 \%$, the trust factor with an average weight of $93 \%$, and the shopping experience with an average weight. $59.3 \%$ can attract consumer buying interest on the online shopping site Shopee.
\end{abstract}

Keywords : Consumer Buying Interest, Online Shop, Shopee

\begin{abstract}
Abstrak
Pada saat ini kebanyakan orang lebih memilih untuk berbelanja di situs online karena keamanan, kemudahan, kepercayaan, dan pengalaman berbelanja yang di tawarkan oleh situs online. Tujuan dari penelitian ini yaitu untuk menganalisis faktor-faktor yang dapat mempengaruhi minat beli konsumen pada situs belanja online Shopee, faktor-faktor tersebut diantaranya yaitu faktor keamanan, faktor kemudahan, faktor kepercayaan, dan pengalaman berbelanja. Pada penelitian ini penulis memilih warga Desa semingkir yang berjumlah 3000 orang untuk dijadikan sebagai populasi atau objek yang akan diteliti. Teknik pengambilan sampel yang digunakan dalam penelitian ini adalah teknik purposive sampling, dimana responden memiliki kemampuan yang sama dalam mengaplikasikan situs belanja online dijadikan sebagai kriteria, sehingga didapat jumlah sampel yang digunakan yaitu sebanyak 91 sampel. Dalam penelitian ini metode analisis yang digunakan yaitu melalui wawancara, observasi, dan studi pustaka. Hasil penelitian yang didapat menunjukkan bahwa faktor keamanan dengan rata-rata bobot sebesar 94,8\%, faktor kemudahan dengan rata-rata bobot $70,3 \%$, faktor kepercayaan dengan rata-rata bobot sebesar 93\%, dan pengalaman berbelanja dengan rata-rata bobot 59,3\% dapat menarik minat beli konsumen di situs online shop Shopee.
\end{abstract}

Kata kunci : Minat Beli Konsumen, Online Shop, Shopee

\section{Pendahuluan}

Semakin pesatnya teknologi informasi yang berkembang saat ini salah satunya pada penggunaan internet, sangat berdampak pada seluruh aspek kehidupan seperti pada bidang bisnis. Penggunaan internet bukan hanya sebagai penyedia informasi melalui media, namun juga digunakan sebagai media guna melakukan kegiatan jual beli atau perdagangan melalui situs markerplace. Asosisasi Penyelenggara 
Jasa Internet Indonesia (APJII) melakukan survey pada tahun 2020, hasil survey tersebut menjelaskan bahwa di Indonesia pada kuartal II tahun 2020 pengguna internet menembus angka 196,7 juta atau $7,37 \%$ dari populasi penduduk. Penggunaan internet pada periode 2019 sampai kuartal II ditahun 2020 ini menunjukkan peningkatan yang cukup signifikan dibanding pada tahun sebelumnya, kenaikan pengguna internet di Indonesia sebesar $8,9 \%$ atau sama dengan 25,5 juta pengguna, jumlah pengguna ini dianggap semakin lama akan terus semakin meningkat. Banyak yang memanfaatkan hal tersebut menjadi sebuah peluang bisnis dengan membangun toko online di berbagai tempat penjualan yang berbasis teknologi atau elektronik (e-commerce).

Electronic Commerce atau yang sering disebut dengan E-Commerce ini memiliki arti bahwa sistem pemasaran sekarang ini dapat dilakukan dengan media elektronik. Adapun aktivitas yang terdapat didalam Electronic Commerce tersebut meliputi distribusi, penjualan, pembelian, marketing dan service dari sebuah produk yang dilakukan dalam sebuah system elektronika seperti Internet atau bentuk jaringan komputer yang lain (Wibowo, 2016). Pada saat ini belanja online sedang marak di Indonesia melalui marketplace, dengan keamanan, kemudahan, kepercayaan yang sesuai dengan keinginan konsumen, maka akan dapat menarik minat konsumen dalam hal pembelian secara online. Menurut Bakti, Hairudin and Alie, (2020) minat beli adalah suatu tindakan atau perilaku dari pembeli dimana pembeli memiliki hasrat pada saat akan menentukan dan memakai, atau timbul rasa ingin memiliki pada barang yang sedang dijual. Sebelum menentukan untuk melakukan pembelian secara online, seseorang biasanya mencari informasi terlebih dahulu mengenai situs online yang dapat membuatnya tertarik untuk melakukan pembelian pada situs online tersebut.

Marketplace yang banyak digunakan di Indonesia salah satunya adalah situs belanja online Shopee yang sudah hadir di Indonesia sejak tahun 2015. Shopee dipilih sebagai objek dalam penelitian ini karena Shopee merupakan platform e-commerce yang banyak dikunjungi oleh pengguna layanan jasa, dilansir dari portal berita kontan.co.id, dari beragam platform ecommerce yang hadir di tengah masyarakat Indonesia, Shopee menjadi layanan ecommerce yang sering dijelajahi dan sering dipakai untuk melakukan belanja online oleh masyarakat pada tahun 2020 (Pratama Afrianto and Irwansyah, 2021). Perusahaan yang yang berasal dari Singapura ini berhasil memberikan kontribusi berupa pertumbuhan market SEA Sebagai pendatang baru di bisnis e-commerce Indonesia, Shopee berhasil mengambil perhatian banyak orang atau yang sering kita sebut dengan netizen. Menurut Feriyansyah (2018) dalam penelitian yang dilakukan oleh Cheetah menjelaskan bahwa Shopee memiliki peningkatan yang cukup signifikan ini dapat menduduki peringkat pertama dengan jumlah presentase pengguna aktif sebesar 3,99\% setiap minggunya. Di Indonesia transaksi yang diperoleh dari Shopee dapat dikatakan sebagai transaksi terbesar di ASEAN, karena dapat dilihat bahwa saat pertama di rilis pada kuartal ke-3 tahun 2015, aktivitas penjualan di Indonesia yang dilakukan melalui smartphone menembus 56\%, Di Indonesia juga Shopee memiliki listing aktif lebih dari 55 juta dan unduhan aplikasi lebih dari 15 juta sedangkan pada Shopee regional memiliki total nilai transaksi lebih dari US\$ 3 milliar dengan unduhan aplikasi pada paruh pertama tahun 2017 lebih dari 40 juta (Edward and Utami, 2020). Data tersebut dianggap sebagai penanda bahwa seiring berjalannya waktu pertumbuhan ekonomi digital terutama e-commerce memiliki peluang untuk tumbuh menjadi lebih baik lagi.

Marketplace yang banyak digunakan di Indonesia salah satunya adalah situs belanja online Shopee yang sudah hadir di Indonesia sejak tahun 2015. Shopee dipilih 
sebagai objek dalam penelitian ini karena Shopee merupakan platform e-commerce yang banyak dikunjungi oleh pengguna layanan jasa, dilansir dari portal berita kontan.co.id, dari beragam platform ecommerce yang hadir di tengah masyarakat Indonesia, Shopee menjadi layanan ecommerce yang sering dijelajahi dan sering dipakai untuk melakukan belanja online oleh masyarakat pada tahun 2020 (Pratama Afrianto and Irwansyah, 2021). Perusahaan yang yang berasal dari Singapura ini berhasil memberikan kontribusi berupa pertumbuhan market SEA Sebagai pendatang baru di bisnis e-commerce Indonesia, Shopee berhasil mengambil perhatian banyak orang atau yang sering kita sebut dengan netizen. Menurut Feriyansyah (2018) dalam penelitian yang dilakukan oleh Cheetah menjelaskan bahwa Shopee memiliki peningkatan yang cukup signifikan ini dapat menduduki peringkat pertama dengan jumlah presentase pengguna aktif sebesar 3,99\% setiap minggunya. Di Indonesia transaksi yang diperoleh dari Shopee dapat dikatakan sebagai transaksi terbesar di ASEAN, karena dapat dilihat bahwa saat pertama di rilis pada kuartal ke-3 tahun 2015, aktivitas penjualan di Indonesia yang dilakukan melalui smartphone menembus $56 \%$, Di Indonesia juga Shopee memiliki listing aktif lebih dari 55 juta dan unduhan aplikasi lebih dari 15 juta sedangkan pada Shopee regional memiliki total nilai transaksi lebih dari US\$ 3 milliar dengan unduhan aplikasi pada paruh pertama tahun 2017 lebih dari 40 juta (Edward and Utami, 2020). Data tersebut dianggap sebagai penanda bahwa seiring berjalannya waktu pertumbuhan ekonomi digital terutama e-commerce memiliki peluang untuk tumbuh menjadi lebih baik lagi.

Shopee memiliki konsep pasar mobile sentris yang berarti pengguna dapat menelusuri barang, berbelanja, serta memperdagangkan suatu barang dengan waktu yang tidak terbatas. Pada awalnya model bisini yang digunakan oleh Shopee yaitu model bisnis $\mathrm{C} 2 \mathrm{C}$ (customer to customer), tetapi dengan perkembangan yang ada maka terciptalah Shopee Mall. Oleh karena itu business model pada Shopee berubah menjadi bisnis untuk pelanggan (business to customer - B2C) serta model hibird $\mathrm{C} 2 \mathrm{C}$.

Tidak semua orang tertarik melakukan pembelian disitus online, terdapat beberapa orang yang masih belum tertarik dalam melakukan pembelian di onlineshop atau berbelanja secara online dengan alasan karena tidak percaya pada penjualan secara online, kesulitan dalam melakukan transaksi online, serta rasa takut akan barang yang datang tidak sesuai pesanan. Dengan masalah tersebut, maka minat dalam melakukan belanja online akan berkurang. Hal tersebut menuntut para pelaku usaha online untuk dapat menarik minat beli konsumen dengan memperhatikan faktorfaktor yang dapat mempengaruhi minat beli seseorang untuk melakukan belanja online. Faktor-faktor tersebut diantaranya yaitu keamanan, kemudahan, kepercayaan, dan pengalaman berbelanja online.

Adapun tujuan dari penelitian ini adalah untuk melakukan analisis terhadap faktor-faktor yang dapat mempengaruhi minat beli konsumen saat melakuakan pembelian online pada Shopee. Faktorfaktor dibatasi pada aspek keamanan, kemudahan, kepercayaan, dan pengalaman berbelanja online.

\section{Tinjauan Pustaka}

Nurrahmanto (2015), mengemukakan bahwa kemudahan penggunaan, kenikmatan berbelanja, dan kepercayaan konsumen, berpengaruh positif dan signifikan terhadap minat beli konsumen pada situs jual beli online Bukalapak.com. Variabel pengalaman berbelanja memiliki berpengaruh positif dan tidak signifikan terhadap minat beli konsumen pada situs jual beli online Bukalapak.com.

Rosdiana and Haris (2018), berpendapat bahwa variabel kepercayaan 
berpengaruh positif dan signifikan terhadap minat beli konsumen dalam berbelanja secara online. Selanjutnya, menurut Adi (2017), dalam penelitiannya menunjukkan bahwa kepercayaan, harga, dan kemudahan memiliki pengaruh positif secara signifikan terhadap minat beli konsumen di situs OLX.co.id.

Keamanan menurut Sarjita (2020) yaitu kemampuan onlineshop dalam melaksanakan pengawasan serta menjaga adanya ancaman atas transaksi data, pertangungan pengawasan ini memiliki peran penting dalam membentuk kepercayaan dengan meminimalkan perhatian konsumen mengenai penyalahgunaan data pribadi dan transaksi data yang mudah rusak. Keamanan menjadi faktor utama dalam kegiatan bisnis online yang digunakan untuk mencegah adanya ancaman terutama pada transaksi online. Dengan menjaga sistem keamanannya maka dapat memberi kenyamanan pada pihak konsumen sehingga konsumen tidak akan merasa cemas dengan penyalahgunaan data pribadi saat melakukan belanja disitus online.

Menurut Setyarko (2016), kemudahan dalam penggunaan merupakan suatu hal yang dapat menjadi pertimbangan bagi konsumen, gambaran yang dihasilkan konsumen berkaitan dengan kemudahan dalam penggunaan dijadikan sebagai tolak ukur untuk mengetahui sejauh mana keyakinan yang diharapkan konsumen pada sebuah teknologi informasi yang tidak akan menyulitkan konsumen dalam beradaptasi baik secara fisik maupun mental. Apabila penggunaan situs belanja online ternyata sulit atau rumit, maka konsumen akan enggan untuk melakukan pembelian secara online. Namun apabila situs onlineshop mudah digunakan, maka konsumen akan menggunakan situs tersebut untuk melakukan pembelian online.

Kepercayaan menurut Anwar (2016), adalah suatu pokok utama yang harus diperhatikan dalam proses bisnis. Transaksi yang dilakukan oleh kedua belah pihak atau lebih akan dapat berjalan dengan baik apabila saling mempercayai satu sama lain. Dalam sebuah bisnis kepercayaan tidak dapat timbul secara langsung, tetapi perlu dibentuk sejak bisnis tersebut didirikan. Dengan hal ini pelaku bisnis online harus berusaha memunculkan rasa yakin terhadap konsumen agar timbul rasa percaya pada produk yang akan dibeli. Langkah yang dapat dilakukan untuk menanamkan rasa percaya dalam diri konsumen yaitu dengan menjaga kualitas baik produk maupun pelayanan, memperhatikan tampilan situs, serta foto produk yang akan dijual. Selain itu popularitas situs juga dapat membangun rasa percaya pada konsumen, dimana semakin banyak yang menyukai dan menggunakan situs tersebut, maka konsumen semakin memiliki keyakinan untuk melakukan pembelian dionlineshop tersebut.

Pegalaman berbelanja online menurut Arifin (2016) memiliki arti bahwa seseorang pernah mengalami, menjalani, dan merasakan berbelanja di onlineshop. Semakin banyak konsumen mengalami pengalaman yang baik atau positif, maka akan semakin mendorong minat beli mereka untuk dapat kembali melakukan pembelian pada situs belanja online tersebut.

Menurut Anwar (2016), minat beli konsumen merupakan suatu planning yang akan dilakukan oleh konsumen dalam melakukan suatu pembelian produk dengan mempertimbangakan empat aspek, yaitu banyaknya komponen produk yang diperlukan dalam jangka waktu yang telah ditentukan, brand, dan sudut pandang dari konsumen pada saat mengunakan produk tersebut. Menurut Bakti, Hairudin and Alie (2020) Terdapat empat indikator minat beli konsumen diantaranya yaitu minat transaksional, minat referensial, minat preferensial, dan minat eksploratif :

$$
\begin{aligned}
& \text { 1. Minat Transaksional, } \\
& \text { merupakan keinginan seseorang }
\end{aligned}
$$


dalam melakukan pembelian di onlineshop.

2. Minat Referensial, adalah keinginan seseorang dalam menyarankan produk kepada orang lain.

3. Minat Preferensial, meggambarkan sikap dari idividu yang mempunyai kesukaan pada produk tersebut atau produk tersebut menjadi pilihan utamanya.

4. Minat Eksploratif, menggambarkan sikap dari individu yang kerap menggali informasi tentang barang yang diinginkannya serta menggali informasi guna menunjang sifatsifat positif dari barang tersebut.

\section{Metode Penelitian}

Dalam penelitian ini metode yang digunakan adalah metode kualitatif deskriptif, metode kualitatif merupakan suatu metode yang mejelaskan dan mengartikan data-data yang telah tergabung melalui pemberian atensi serta mencatat sejumlah aspek situasi yang diteliti pada waktu itu, sehingga diperoleh gambaran secara komprehensif mengenai peristiwa sebenarnya, kemudian melalui metode deskriptif yang artinya peneliti menganalisis data yang telah tergabung yang meliputi kata-kata, gambar dan bukan angka-angka, dimana data data yang diperoleh terdiri dari hasil wawancara, catatan lapangan, foto, video tape, dokumen pribadi, catatan atau memo dan dokumen resmi lainnya yang telah dilakukan oleh peneliti (Akhmad, 2015).

Pada penelitian ini penulis memilih warga Desa Semingkir yang berjumlah 3000 orang untuk dijadikan sebagai populasi atau objek yang akan diteliti, untuk teknik pengambilan sampel yang digunakan pada penelitian ini yaitu dengan teknik purposive sampling, menurut Model et al. (2015) purposive sampling merupakan suatu teknik pengumpulan sampel dengan penilaian spesifik. Rumus yang digunakan untuk menentukan jumlah sampel pada penelitian ini yaitu :

$$
\begin{aligned}
\mathrm{n} & =\frac{Z^{2} a / 2 * P(1-P) N}{d^{2}(N-1)+Z^{2} a / 2 * p(1-p)} \\
\mathrm{n} & =\frac{1,96^{2} \times 0,55(1-0.55) \cdot N}{0,1^{2}(N-1)+1,96^{2} \cdot 0,55(1-0,55)} \\
& =\frac{3,8 \cdot 0,55 \cdot 0,45 \cdot N}{0,01 \cdot(N-1)+3,8 \cdot 0,55 \cdot 0,45} \\
& =\frac{0,94 \cdot N}{0,01(N-1)+0,94} \\
& =\frac{0,94 \cdot 3000}{0,01(3000-1)+0,94} \\
& =\frac{2820}{29,99+0,94} \\
& =\frac{2820}{30,93} \\
\mathrm{n} & =91,17
\end{aligned}
$$

Jadi menurut perhitungan di atas, sehingga dapat diketahui bahwa jumlah sampel yang diperlukan adalah sejumlah 91 responden dengan kriteria responden tersebut menguasai internet dan memiliki kemampuan yang sama dalam mengaplikasikan situs belanja online.

Jenis data dalam penelitian ini adalah data primer dan data sekunder. Data primer ini didapatkan oleh peneliti dari informasi yang diberikan oleh informan, dimana informasi tersebut diperoleh dari hasil wawancara dan observasi pada warga Desa Semingkir. Sedangkan data sekunder adalah data yang berasal dari studi literatur, jurnal, krya tulis, dan lain-lain yang digunakan sebagai data pendukung yang berkaitan dengan penelitian. Pada penelitian ini teknik penelitian data yang digunakan adalah dengan cara melakukan wawancara, observasi, dan dokumentasi.

\section{Hasil dan Pembahasan}

Berdasarkan metode yang digunakan yaitu metode kualitatif dan kuesioner yang disebarkan pada 91 responden atau konsumen onlineshop Shopee, maka penelitian ini mendapatkan hasil yang dapat dijelaskan sebagai berikut :

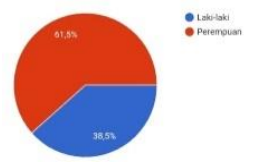


Diagram lingkaran diatas menunjukkan bahwa pengguna situs belanja online Shopee di Desa Semingkir sebanyak $38,5 \%$ merupakan pengguna laki-laki dan $61,5 \%$ merupakan pengguna perempuan.

Diagram lingkaran faktor keamanan

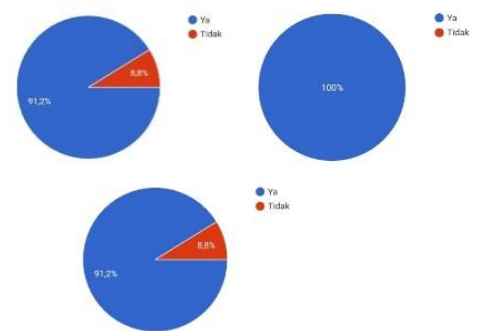

Hasil analisis faktor keamanan pada diagram diatas menunjukkan bahwa minat beli konsumen berada pada rentang skala yang baik dengan jumlah rata-rata bobot sebanyak 94,8\%, berarti disini responden merasakan situs belanja online Shopee dapat memberikan keamanan privasi dengan melindungi informasi data pribadi yang menimbulkan kesan positif atau responden tidak merasa bahwa data pribadi mereka akan digunakan untuk halhal yang dapat merugikan pada saat akan melakukan pembelian disitus belanja online Shopee. Hal ini dapat membuktikan bahwa faktor keamanan dapat menarik minat konsumen untuk membeli produk pada situs belanja online Shopee. Sisanya yaitu sebesar $5,1 \%$ merasa tidak aman pada saat melakukan pembelian di Shopee.

kemudahan

Diagram lingkaran faktor

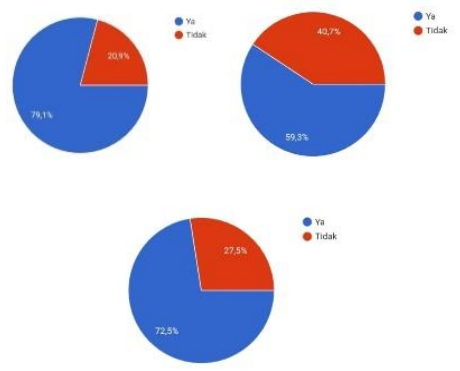

Berdasarkan hasil analisis faktor kemudahan pada diagram diatas menunjukkan bahwa minat beli konsumen berada pada rentang skala yang baik dengan rata-rata bobot sebesar $70,3 \%$, berdasarkan hasil rata-rata bobot tersebut dapat diketahui bahwa responden merasakan kemudahan dalam penggunaan aplikasi situs belanja online Shopee seperti pada saat melakukan pencarian maupun kemudahan dalam metode pembayaran dimana Shopee menyediakan beberapa pilihan metode pembayaran salah satunya yaitu dengan metode bayar ditempat (Cash on Delivery) yang sangat memudahkan pengguna. Hal ini dianggap dapat menarik minat konsumen untuk berbelanja di Shopee. Dan sebanyak $29,7 \%$ responden beranggapan bahwa tidak merasakan kemudahan dalam penggunaan dan transaksi pada situs belanja online Shopee.

Diagram faktor kepercayaan :

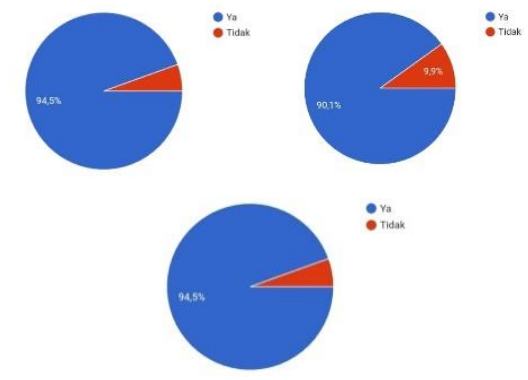

Hasil analisis faktor kepercayaan pada diagram diatas menunjukkan bahwa minat beli konsumen berada pada rentang skala yang baik, dengan jumlah rata-rata bobot sebanyak 93\%, berarti disini responden memiliki rasa percaya pada saat melakukan pembelian di Shopee karena kualitas produk yang dipesan bagus dan sesuai dengan deskripsi dari penjual, serta produk yang dipesan juga sampai sebelum melebihi batas waktu atau tanggal yang telah ditentukan. Hal ini dapat membuktikan bahwa faktor kepercayaan dapat menarik minat konsumen untuk berbelanja di Shopee. Kemudian 7\% responden masih kurang memiliki rasa percaya saat akan berbelanja di Shopee.

Diagram lingkaran faktor pengalaman berbelanja :

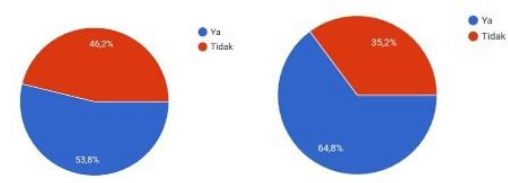

Hasil analisis faktor pengalaman berbelanja dilihat pada diagram lingkaran 
diatas menunjukkan bahwa minat beli konsumen berada pada rentang skala yang cukup baik dengan rata-rata bobot sebesar $59,3 \%$ yang berarti bahwa responden mendapatkan pengalaman yang positif setelah berbelanja di Shopee seperti merasa senang setelah berbelanja di Shopee, serta merasakan pelayanan yang memuaskan dari si penjual, hal tersebut dapat berindikasi pada responden yang akan melakukan pembelian ulang pada Shopee. Oleh karena itu, faktor pegalaman berbelanja dikatakan dapat meningkatkan minat beli konsumen serta pembelian ulang pada situs onlineshop Shopee. Kemudian 40,7\% responden merasa tidak mendapatkan pengalaman positif pada saat berbelanja di Shopee.

\section{KESIMPULAN}

Berdasarkan pada hasil analisis dan pembahasan, sehingga peneliti dapat memberikan kesimpulan bahwa faktor keamanan, faktor kemudahan, faktor kepercayaan, dan pengalaman berbelanja dapat menarik minat beli konsumen untuk melakukan pembelian disitus jual beli online Shopee. Pada faktor keamanan dapat meningkatkan minat belikonsumen dengan meindungi informasi data pribadi dari konsumen atau pembeli, faktor kemudahan dapat meningkatkan minat beli konsumen dengan memberi kemudahan pada penggunaan aplikasi dan metode pembayaran yang ditawarkan oleh Shopee, faktor kepercayaan dapat meningkatkan minat beli konsumen melalui pemberikan mutu produk yang setara dengan deskripsi dari penjual serta produk yang sampai dengan tepat waktu, dan faktor pengalaman berelanja dapat menigkatkan minat beli konsumen dengan memberikan rasa senang dan pelayanan yang memuaskan kepada pelanggansehingga menimbulkan pengalaman yang positif setelah melakukan pembelian di Shopee.

Dari keempat faktor yang dapat menarik minat konsumen yaitu faktor keamanan, faktor kemudahan, faktor kepercayaan, dan pengalaman berbelanja, yang paling unggul untuk dapat menarik minat konsumen adalah faktor keamanan dimana faktor ini merupakan faktor paling utama yang kerap menjadi pertimbangan oleh konsumen pada saat akan berbelanja di onlinehop, serta responden merasa aman ketika berbelanja di situs belanja online Shopee karena informasi datanya dilindungi.

Saran yang dapat disampaikan oleh peneliti yaitu agar situs belanja online Shopee tetap dapat mempertahankan faktor keamanannya untuk melindungi data pribadi konsumen saat akan melakukan pembelian atau bertransaksi. Kemudian meningkatkan faktor kemudahan dalam penggunaan pada aplikasi Shopee guna memudahkan transaksi bagi konsumen atau pembeli pada saat berbelanja di Shopee. Penjual juga harus mempertahankan kepercayaan dari pelanggan dengan meningkatkan kualitas, pelayanan ataupun pengiriman. Serta meningkatkan pengalaman belanja, agar konsumen memiliki pengalaman yang positif dan merasa senang saat melakukan pembelian di situs belanja online Shopee.

\section{Daftar Pustaka}

Adi Perwira, R. (2017) 'Pengaruh Kepercayaan, Harga, dan Kemudahan Terhadap Minat Beli Konsumen Pada Toko Online (Studi Pada Toko Online OLX.co,id)', Ekonomi, 53(9), pp. 1-16.

Akhmad, K. A. (2015) 'Pemanfaatan Media Sosial bagi Pengembangan Pemasaran UMKM (Studi Deskriptif Kualitatif pada Distro di Kota Surakarta)', DutaCom Journal, 9(1), pp. 43-54. Available at: http://journal.stmikdb.ac.id/index.ph $\mathrm{p} /$ dutacom/article/view/17.

Anwar, R. and Adidarma, W. (2016) 'PENGARUH KEPERCAYAAN DAN RISIKO PADA MINAT BELI BELANJA ONLINE Rosian Anwar 1 Wijaya Adidarma 2', Jurnal Manajemen Dan Bisnis Sriwajaya, 14, p. 2. 
Arifin, R., Laili, I. N. and Hufron, M. (2016) 'PENGARUH WORD OF MOUTH, PENGALAMAN BELANJA ONLINE, PERSEPSI KEMUDAHAN, DAN PERSEPSI RESIKO TERHADAP MINAT BELANJA KONSUMEN DI SITUS JUAL BELI ONLINE LAZADA (Studi Kasus Pada Mahasiswa UNISMA Fakultas Ekonomi Dan Bisnis Jurusan Manajemen JL.MT.Haryono 193 ', $e-$ JurnalRisetManajemen, pp. 82-94.

Bakti, U., Hairudin and Alie, M. S. (2020) 'Pengaruh Kualitas Pelayanan, Produk dan Harga Terhadap Minat Beli Pada Toko Online Lazada di Bandar Lampung', Jurnal Ekonomi, 22(1), pp. 101-118. Available at: https://mediakonsumen.com/2018/0 5/14/sur.

Edward, M. N. and Utami, S. (2020) 'Pengaruh Nilai Akuisisi Dan Nilai Transaksi Terhadap E-Loyalty Yang Di Mediasi Oleh E-Satisfaction Pada E-Commerce Shopee Di ...', Jurnal Ilmiah Mahasiswa Ekonomi ..., 5(1), pp. 220-235. Available at: http://www.jim.unsyiah.ac.id/EKM/ article/view/14297.

Feriyansyah, Y. (2018) 'Analisis Sistem ECommerce Pada Perusahaan Marketplace Mobile Shopee Indonesia', Seminar Nasional Sistem Informasi dan Teknologi Informasi, STMIK Pontianak, p. 565. Available at:

http://sisfotenika.stmikpontianak.ac. id/index.php/sensitek/article/viewFil $\mathrm{e} / 315 / 268$.

Model, P. et al. (2015) 'Pengembangan Model Bimbingan Klasikal Dengan Teknik Role Playing Untuk Meningkatkan Kepercayaan Diri', Jurnal Bimbingan Konseling, 4(1), pp. 36-42.

Nurrahmanto, Agus Prasetyo Rahardja, P. (2015) 'Pengaruh Kemudahan Penggunaan, Kenikmatan berbelanja, pengalaman Berbelanja
Dan Kepercayaan Konsumen Terhadap Minat Beli Konsumen Di Situs Jual Beli Online Bukalapak.com', Diponegoro journal of management, 4(2012), pp. $1-12$.

Pratama Afrianto, A. and Irwansyah, I. (2021) 'Eksplorasi Kondisi Masyarakat Dalam Memilih Belanja Online Melalui Shopee Selama Masa Pandemi Covid-19 Di Indonesia', Jurnal Teknologi Dan Sistem Informasi Bisnis, 3(1), pp. 10-29. doi: 10.47233/jteksis.v3i1.181.

Rosdiana, R. and Haris, I. A. (2018) 'Pengaruh Kepercayaan Konsumen Terhadap Minat Beli Produk Pakaian Secara Online', International Journal of Social Science and Business, 2(3), p. 169 . doi: 10.23887/ijssb.v2i3.16240.

Sarjita (2020) 'Pengaruh Kepercayaan Dan Keamanan Terhadap', VII(1), pp. 69-82.

Setyarko, Y. (2016) 'Analisis Persepsi Harga, Promosi, Kualitas Pelayanan, dan Kemudahan Penggunaan Terhadap Keputusan Pembelian Produk Secara Online', Ekonomika dan Manajemen, ISSN: 2252-6226, 5(2), pp. 128-147.

Wibowo, E. A. (2016) 'Pemanfaatan Teknologi E-Commerce Dalam Proses Bisnis', Equilibiria, 1(1), pp. 95-108. Available at: http://journal.unrika.ac.id/index.php /equi/article/view/222. 